\title{
Estuarine Ecosystem Response Captured Using a Synoptic Climatology
}

\author{
David G. Kimmel • W. David Miller • \\ Lawrence W. Harding Jr • Edward D. Houde • \\ Michael R. Roman
}

Received: 29 October 2008 /Revised: 3 February 2009 / Accepted: 4 February 2009 / Published online: 25 February 2009

(C) Coastal and Estuarine Research Federation 2009

\begin{abstract}
Estuarine and coastal ecosystems respond strongly to proximate climate forcing. In this study, we present a regional, synoptic climatology as an approach to classify weather patterns that generate interannual variability in coastal and estuarine ecosystems. Synoptic climatology is a method that classifies sea level pressure data into distinct patterns representing common weather features for a specified region. A synoptic climatology was developed for the eastern United States and used to quantify surface conditions affecting Chesapeake Bay during wet and dry years. In a synthesis analysis, several mechanisms were identified that explained the link between weather patterns and ecosystem structure, principal among them is the delivery of freshwater to the Bay during spring. Wet and dry years were characterized by shifts in biogeography of the Chesapeake Bay. The shifts resulted from habitat
\end{abstract}

D. G. Kimmel · W. D. Miller $\cdot$ L. W. Harding Jr $\cdot$ M. R. Roman Horn Point Laboratory,

University of Maryland Center for Environmental Science,

P.O. Box 775, Cambridge, MD 21613, USA

W. D. Miller

National Research Council, US Naval Research Laboratory,

4555 Overlook Avenue, SW,

Washington, DC 20375, USA

E. D. Houde

Chesapeake Biological Laboratory,

University of Maryland Center for Environmental Science,

P.O. Box 38/1 Williams Street,

Solomons, MD 20688, USA

D. G. Kimmel $(\bowtie)$

Department of Biology/Institute for Coastal Science and Policy,

East Carolina University,

Greenville, NC 27858, USA

e-mail: kimmeld@ecu.edu changes and trophic interactions and included the timing and magnitude of the spring phytoplankton bloom, the distribution/abundance of mesozooplankton and gelatinous zooplankton, and juvenile indices of fish. Synoptic climatology resolved regional weather variability at a spatial scale not strongly controlled by larger-scale climate indices and explained ecosystem responses in Chesapeake Bay.

Keywords Synoptic climatology $\cdot$ Large-scale climate indices · Estuary . Chesapeake Bay · Multiple trophic levels

\section{Introduction}

Climate variability can lead to significant shifts in the structure of marine ecosystems (Greene and Pershing 2007; Steele 2004). Notable examples include plankton communities in the North Atlantic and pelagic fish populations in the coastal Pacific Ocean (Fromentin and Planque 1996; Hollowed et al. 2001). Specifying climate forcing of ecosystem responses requires metrics of climate variability and data of sufficient spatial and temporal resolution to resolve the responses (Hollowed et al. 2001; Ottersen et al. 2001; Pearcy and Shoener 1987). Widely applied indices of ocean-atmosphere processes, such as the North Atlantic Oscillation (NAO), Pacific Decadal Oscillation (PDO), and El Niño Southern Oscillation (ENSO) integrate climate phenomena over large spatial scales (Stenseth et al. 2003). These indices have proven effective to explain shifts of species abundances and community composition evident in long-term data. Results from the Continuous Plankton Recorder in the North Atlantic, for example, link abundances and composition of copepods to NAO variability (Fromentin and Planque 1996). Fisheries landings in Japan have been related to ENSO (Sugimoto et al. 2001) and 
fisheries landings and recruitments to the NAO (Brunel and Boucher 2007) and PDO (Beamish and Noakes 2002; Hollowed et al. 2001). Analyses based on indices of these large-scale processes have advanced our understanding of ecosystem responses driven by climate, but they suffer significant limitations (Stenseth et al. 2003). Specifically, the link between climate indices and local conditions is often weak and difficult to quantify for regions not under the strong influence of large-scale ocean-atmosphere interactions (Tootle et al. 2005) or for those expressing variability on different temporal scales than are captured by these large-scale indices.

An example where large-scale ocean-atmospheric forcing fails to capture ecosystem responses is Chesapeake Bay, the largest estuary in the United States. As with other estuaries, including Perdido Bay, Florida, USA (Macauley et al. 1995), San Francisco Bay, California, USA (Cloern 1996; Cloern et al. 1983), the Neuse-Pamlico estuary, North Carolina, USA (Paerl et al. 2006a, b), and Apalachicola Bay, Florida, USA (Livingston et al. 1997), the Chesapeake is strongly influenced by its surrounding watershed. As such, the estuary is highly susceptible to climate forcing as the watershed integrates the effects of climate over land. One of these effects is the annual timing and magnitude of freshwater flow. The main source of freshwater flow to Chesapeake Bay, the Susquehanna River, varied threefold over the last 52 years (Miller et al. 2006). Ecosystem responses to variability of freshwater flow expressed in phytoplankton (Harding 1994), zooplankton (Kimmel and Roman 2004), gelatinous zooplankton (Purcell and Decker 2005), and fish (Jung and Houde 2003; Wood 2000) are documented for this and other estuaries (Dippner et al. 2001; Lehman 2004). Indices of large-scale processes such as NAO, PDO, or ENSO (Tootle et al. 2005) fail to explain this variability because coastal plain estuaries of the Middle Atlantic region are more strongly affected by proximal climate forcing.

To address the role of climate forcing on a regional scale, we applied a synoptic climatology based on patterns of sea level pressure (SLP) as an alternative approach to classify and quantify climate variability in the eastern United States (Yarnal 1993). Synoptic climatology is an established approach in physical geography (Yarnal 1993), but its application to ecological studies has been more recent (Wood 2000; Dippner et al. 2001). The purpose of this short paper is to summarize the synoptic climatology approach and provide an example of its application to biological data for Chesapeake Bay. In this study, we synthesize research results from individual publications and add new biological data from Chesapeake Bay to illustrate how the entire ecosystem responds to differential climate forcing.

\section{Materials and Methods}

Gridded, daily SLP (mb) data were acquired (0 and 12:00 UTC), $5^{\circ}$ latitude by $5^{\circ}$ longitude, from the National Center for Atmospheric Research (http://dss.ucar.edu). These data (1950-2002) were used to classify common weather patterns for a study area bounded by $25-50^{\circ} \mathrm{N}, 65-100^{\circ} \mathrm{W}$ (Yarnal 1993). We identified predominant weather patterns using an Eigen vector-based, map pattern classification procedure. The weather patterns that emerged were related to surface conditions using divisional data from the United States National Climate Data Center (http://cdo.ncdc.noaa.gov). Temperature and precipitation data covered the entire Susquehanna River watershed. Data on freshwater flow for the Susquehanna River were obtained from the United States Geological Survey gauging station at Harrisburg, PA, USA (USGS-01570500; http://waterdata.usgs.gov). Weather pattern anomalies were derived by taking the long-term (19502002) average number of days each pattern occurred during winter (December-February) and subtracting the average from the number of days each pattern occurred during a particular winter. Winter was used to categorize the weather patterns because a strong correlation exists between winter precipitation and spring discharge (Najjar 1999). The arithmetic mean anomaly for five representative wet (see below) and dry (see below) years is reported. The same protocol was used to calculate winter precipitation and air temperature anomalies and spring (March-May) discharge anomaly. Wet and dry years were selected using the following criteria. We summarized the Harrisburg freshwater flow data from 1950 to 2002, calculating the minimum, 25th percentile, median, 75th percentile, and maximum. Years that had flow values $<25$ th percentile were considered dry years and years that had flow values $>75$ th percentile were considered wet years. Due to data limitations for some biological variables, we could only choose years from 1985 to 2002 for the analysis. The five wettest $(1993,1994,1996$, 1998, and 2000) and driest years (1985, 1988, 1990, 1995, and 1999) were chosen during this time frame. Two wet years (1996 and 2000) were below the 75th percentile, but well above the median flow.

Data on chlorophyll $a$ (in milligrams per cubic meter), copepods Eurytemora affinis (number per cubic meter), and ctenophores Mnemiopsis leidyi (milliliters per sample; samples are relative abundance and not normalized by volume filtered) were obtained from the United States Environmental Protection Agency Chesapeake Bay Program (http://www.chesapeakebay.net). Data on medusa Chrysaora quinquecirrha (surface count) were from Breitburg and Fulford (2006). Fish juvenile indices (relative abundance in relation to other species sampled) were from the Maryland Department of Natural Resources (DNR) Fisheries Service (http://www.dnr.state.md.us/fisheries/ 
juvindex/index.html). Fish juvenile index values are annual estimates of young-of-the-year abundances reported by Maryland DNR Fisheries Service and are the geometric mean of each species sampled in seine nets at three time periods (July, August, and September) at 22 fixed stations in the Maryland portion of Chesapeake Bay. Arithmetic means for chlorophyll $a$ were calculated for three geographic regions of Chesapeake Bay, upper $\left(>39.0^{\circ} \mathrm{N}\right)$, middle $\left(>38.0^{\circ} \mathrm{N}\right)$, and lower $\left(<38.0^{\circ} \mathrm{N}\right)$. Arithmetic means for E. affinis abundance during spring (MarchMay) and M. leidyi abundance and C. quinquecirrha counts during summer (June-August) were calculated for the Maryland portion of Chesapeake Bay $\left(>37.75^{\circ} \mathrm{N}\right.$ latitude) of the five representative wet and dry years. Statistical comparisons were made using two-sample $t$ test. Data were transformed where necessary to ensure normality and variances were tested for homogeneity using the $F$ test (Sokal and Rohlf 1995). All variances were homogenous, with the exception of menhaden and spring discharge.

\section{Dry Conditions}
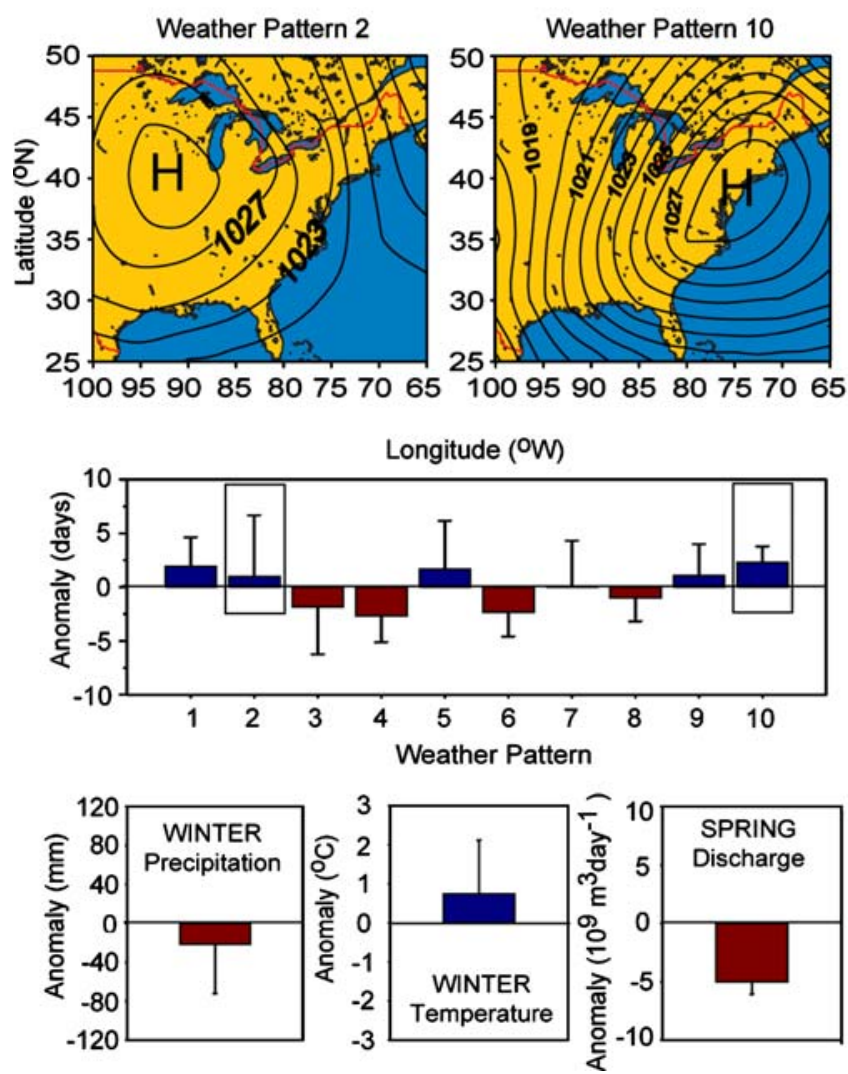

Fig. 1 Winter weather pattern, precipitation, temperature, and spring discharge anomalies during wet or dry conditions. Weather pattern maps are SLP (mb) and represent weather patterns that are typical of each condition (squared box). Weather pattern anomalies are cumulative daily frequencies for each pattern during December-February subtracted from a long-term average (1950-2002) for the five representative wet or dry years (see text). Precipitation anomalies are calculated as cumulative values for December-February over the
Welch's modified two-sample $t$ tests were performed using unequal variances in those cases.

\section{Results and Discussion}

Our analysis identified ten predominant weather patterns (Miller et al. 2006) with distinct frequencies of occurrence, seasonality, and surface conditions (i.e., air temperature, winds, precipitation). Several weather patterns are shown in Fig. 1. These weather patterns were exemplified by several commonly recognized patterns in the region, including a low-pressure storm system known as a Nor'easter (Fig. 1, weather pattern 4) and a continental high-pressure system (Fig. 1, weather pattern 2) (Miller et al. 2006). Cumulative frequencies of the ten weather patterns for winter were used to model freshwater flow into Chesapeake Bay. Multiple linear regression related spring (March-May) freshwater flow from the Susquehanna River to the frequencies of ten

\section{Wet Conditions}
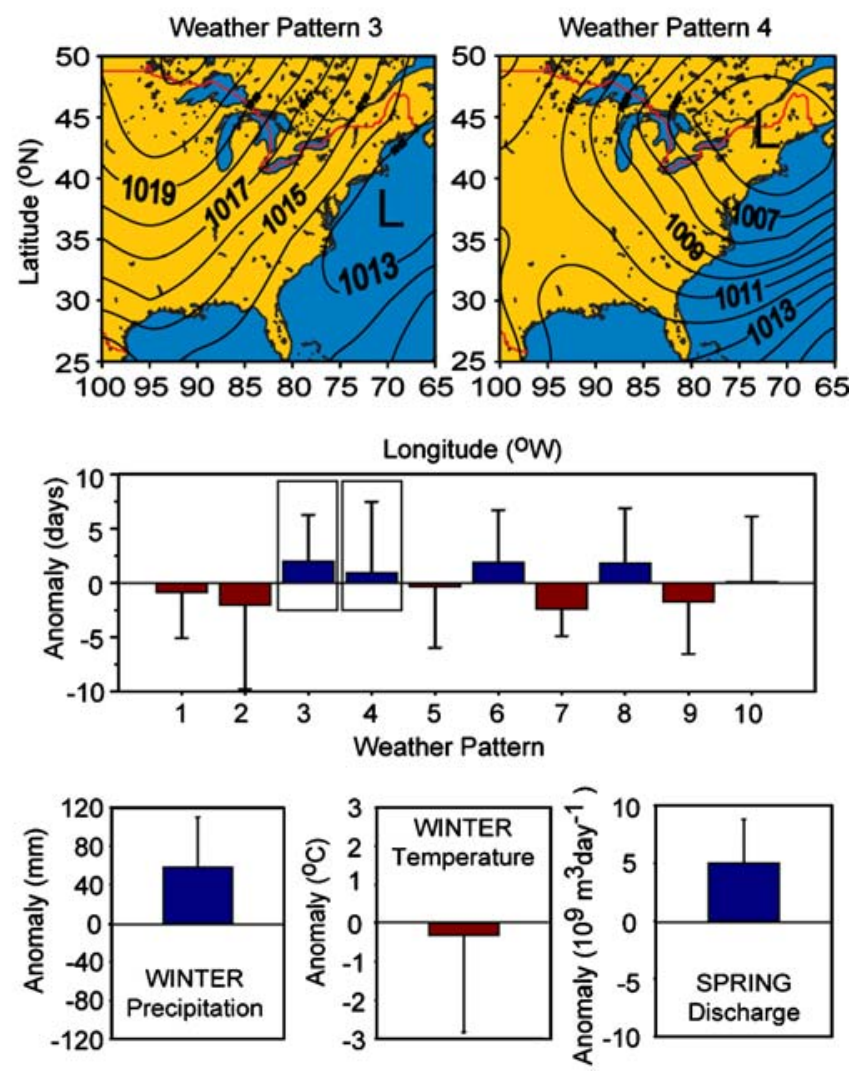

Chesapeake Bay watershed and averaged for the five representative wet or dry years. Winter air temperature anomalies are calculated as average values for December-February over the Chesapeake Bay watershed and averaged for the five representative wet or dry years. Spring discharge anomalies were calculated as cumulative values for March-April and averaged for the five representative wet or dry years. Error bars represent the standard deviation 
weather patterns for winter (December-February), explaining $54 \%$ of the variance (Miller et al. 2006). Synoptic climatology was superior to single-variable indicators of climate (e.g., precipitation, air temperature) because each synoptic pattern integrates multiple surface conditions. For example, using only precipitation and air temperature as predictors explained $17 \%$ of the variance of spring freshwater flow. Our quantitative approach classified weather patterns impacting the Chesapeake region as either "wet" or "dry" and was based on the frequency of weather patterns associated with positive (weather patterns 1, 3, 4, and 8) or negative (weather patterns 2, 7, and 10) anomalies of precipitation (Fig. 1; Miller et al. 2006). Winter air temperature anomalies were not significantly different (two-sample $t$ test, $p>0.05$ ) between "wet" and "dry" years (wet $=0.74 \pm 1.38^{\circ} \mathrm{C}$, dry $=$ $-0.31 \pm 2.52^{\circ} \mathrm{C}$ ), though wet years tended to be warmer than dry years. There was a significant difference in anomalies of winter precipitation and spring discharge during "dry" (precipitation $=-18.24 \pm 36.59 \mathrm{~mm}$, discharge $=-4.62 \pm 1.02 \times$ $10^{9} \mathrm{~m}^{3}$ day $^{-1}$ ) and "wet" (precipitation $=17.37 \pm 58.89 \mathrm{~mm}$; discharge $=4.86 \pm 2.14 \times 10^{9} \mathrm{~m}^{3}$ day $^{-1}$ ) periods (two-sample $t$ test, $p<0.05$ for both precipitation and discharge). Such contrasting "wet-dry" patterns led to high variability of freshwater flow evident in contemporary data and also visible in the paleorecord for the past 500 years (Cronin et al. 2000).

Years dominated by "dry" winter weather patterns delivered low precipitation, resulting in low freshwater flow and nutrient delivery, and supported spring blooms of lower chlorophyll $a$ biomass and covered a restricted area situated landward in the estuary (Fig. 2a). Years dominated by "wet" winter weather patterns delivered high precipitation and associated freshwater flow and nutrient loads, supported spring blooms of higher chlorophyll $a$, and covered a larger area with peak biomass situated toward the seaward terminus of the estuary (Fig. 2b). These contrasting conditions were

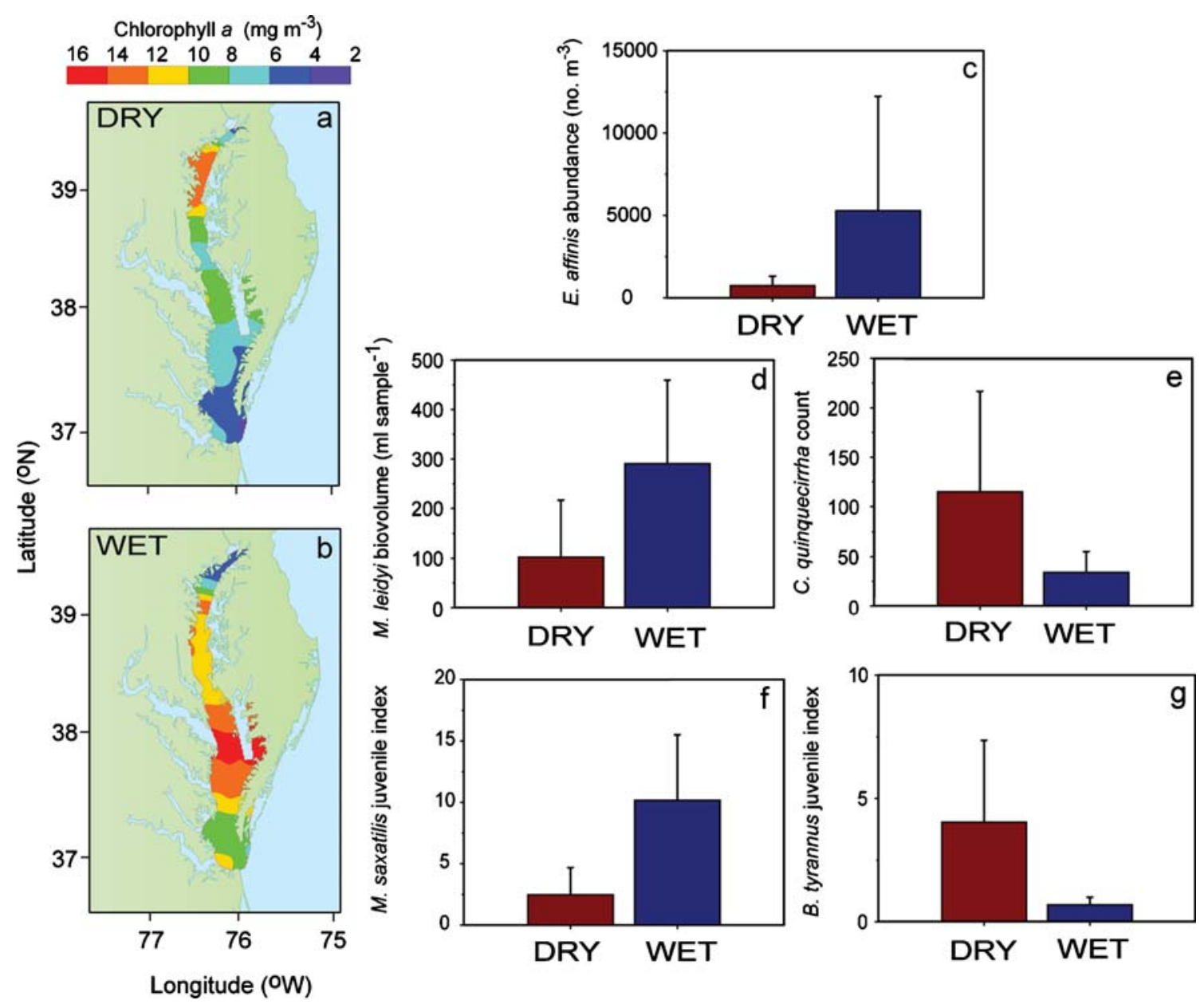

Fig. 2 Biological response in dry and wet years. Spatial distribution of surface chlorophyll $a$ (in milligrams per cubic meter) in Chesapeake Bay during dry years (a) and wet years (b) upper bay abundance of calanoid copepod $E$. affinis (number per cubic meter) (c), lobate ctenophore M. leidyi (milliliters of biovolume per sample) (d), scyphomedusan C. quinquecirrha (count) (e), striped bass M. saxatilis (juvenile index) (f), and Atlantic menhaden B. tyrannus (juvenile index) (g) during wet and dry years. Error bars represent the standard deviation 
quantified as regional means for the upper $\left(>39.0^{\circ} \mathrm{N}\right)$, middle $\left(>38.0^{\circ} \mathrm{N}\right)$, and lower $\left(<38.0^{\circ} \mathrm{N}\right)$ bay, showing significant differences between "dry" and "wet" years (upper= 11.6 vs. $8.3 \mathrm{mg} \mathrm{m}^{-3}$; middle $=8.7$ vs. $12.8 \mathrm{mg} \mathrm{m}^{-3}$; lower $=$ 5.8 vs. $11.1 \mathrm{mg} \mathrm{m}^{-3}$; two-sample $t$ test, $p<0.001$ in all cases). Climate patterns in winter explained the position, areal extent, and magnitude of the spring phytoplankton bloom in Chesapeake Bay (Miller and Harding 2007). Winter weather drove the annual maximum of freshwater flow in spring and generated spatial gradients of light and nutrients. These gradients in turn controlled the distribution and growth of phytoplankton along the north-south axis of the Bay (Harding 1994).

Crustacean zooplankton in Chesapeake Bay were dominated by two species of calanoid copepods, Acartia tonsa and E. affinis. Climate patterns associated with "dry" spring conditions supported significantly lower abundances of $E$. affinis in the upper bay $\left(755.35 \pm 563.62\right.$ number $\left.\mathrm{m}^{-3}\right)$ than those that led to "wet" spring conditions $(5,294.79 \pm$ 6,940.20 number $\mathrm{m}^{-3}$; Fig. 2c; two-sample $t$ test, $p<0.05$ ). Proposed mechanisms linking climate to $E$. affinis suggested increased freshwater flow and a concurrent increase in delivery of detritus, a major food source for E. affinis (Heinle et al. 1977), and an expansion of low-salinity, lowtemperature habitat for this key component of the estuarine food web. Climate did not strongly affect $A$. tonsa whose distribution and abundance in Chesapeake Bay were largely controlled by predation (Kimmel et al. 2006b).

Gelatinous zooplankton were dominated by two species in Chesapeake Bay, the lobate ctenophore, M. leidyi, and the scyphomedusan, C. quinquecirrha. "Dry" winter-spring climate patterns were associated with a significantly lower abundance of $M$. leidyi during summer compared to "wet" winter-springs (two-sample $t$ test, $p<0.05$; Fig. 2d). Higher abundance of $C$. quinquecirrha generally occurred during summers of "dry" years, although missing data for 2000 and high variability led to a nonsignificant difference (twosample $t$ test, $p=0.22$; Fig. 2e). The medusa stage of $C$. quinquecirrha was more abundant in above-average salinity and temperature in spring followed by high temperature in summer. Hydrologic conditions largely explained the observed distributions of C. quinquecirrha and M. leidyi (Purcell and Decker 2005). Low freshwater flow expanded favorable habitat for C. quinquecirrha polyps and production of ephyrae in the early summer (Cargo and King 1990; Purcell et al. 1999).

Climate also significantly affected the production, i.e., recruitment, of juveniles of two important fishes, the striped bass, Morone saxatilis, and its prey, the Atlantic menhaden, Brevoortia tyrannus. The mean abundance of striped bass juveniles collected in late-summer seine samples during "wet" years was $>3$ times higher than during "dry" years (two-sample $t$ test, $p<0.05$; Fig. 2f). The anadromous $M$. saxatilis spawns during spring in tidal freshwater areas of the bay and its tributaries. Winter weather patterns resulting in "wet" springs increased the spatial extent and volume of suitable spawning and nursery habitats (Secor and Houde 1995 ) and the temporal-spatial overlap in production of zooplankton eaten by larval striped bass (Martino 2008), conditions favorable for recruitment. The ocean-spawning B. tyrannus showed an opposite pattern (Fig. $2 \mathrm{~g}$ ) wherein the mean abundance of menhaden juveniles in late-summer seine surveys were higher in "dry" years (two-sample $t$ test, $p=0.07$; Fig. $2 \mathrm{~g}$ ). Although the mechanism is not yet known, it is probable that ingress of menhaden larvae from the continental shelf is enhanced during "dry" winters (Wood 2000).

Ecosystem-scale responses to climate are in part an integrated expression of complex trophic interactions of the bay's biota. Responses in phenology, biogeography, and abundance produce dynamic interactions at each trophic level. For example, "wet" years result in lower abundances of the scyphomedusan C. quinquecirrha, a predator on the ctenophore M. leidyi in the bay (Feigenbaum and Kelly 1984). The increase of M. leidyi in "wet" years is a combination of response to habitat changes, a release from predation by $C$. quinquecirrha, and more zooplankton prey. In another example, high abundance of $E$. affinis in "wet" years supports high growth and survival of striped bass larvae (North and Houde 2006; Martino 2008). Similar, complex interactions exist at all trophic levels in the bay, implicating climate as the factor most responsible for largescale ecosystem changes. Synoptic climatology is an organizing methodology that effectively explains significant amounts of the variability of biotic components, including phytoplankton, zooplankton, and fish, testifying to its strength as an integrator of both habitat changes and trophic interactions that are strongly forced by "wet" and "dry" conditions (Miller et al. 2006).

Prominent indices of ocean-atmosphere phenomena are increasingly used to describe biotic responses to climate on large spatial scales (Stenseth et al. 2002; Brander 2007; Brunel and Boucher 2007; Stenevik and Sundby 2007). On smaller, regional scales that are less sensitive to responses in large-scale, ocean-atmosphere processes, it is better to adopt an approach that classifies climate forcing on more relevant spatial and temporal scales. Synoptic climatology can identify, quantify, and evaluate effects of regional climate variability across trophic levels, particularly for coastal-estuarine ecosystems that cannot be clearly linked to large-scale climate patterns. Our results from Chesapeake Bay support this assertion for years with contrasting winter weather patterns that are responsible for differences in (1) location, areal extent, and magnitude of the annual phytoplankton maximum in spring (Fig. 2a, b; Miller and Harding 2007); (2) abundance of the copepod E. affinis in 
spring (Fig. 2c; Kimmel et al. 2006a); (3) abundance of gelatinous zooplankton in summer (Fig. 2d, e); and (4) juvenile abundance indices of fish in late summer (Fig. 2f, g). Synoptic climatology may, therefore, be used to facilitate ecological forecasts of 3-6 months for spring phytoplankton and zooplankton and summer gelatinous zooplankton, striped bass, and menhaden recruitment, thus providing another tool for resource managers and restoration activities.

Implementing synoptic climatology as a predictive tool to quantify effects of climate forcing on biological communities is highly relevant to the needs of resource managers that wish to distinguish natural variability (Sherman et al. 2006) from human-induced responses (Landres et al. 1999), a serious challenge in highly variable estuarine and coastal ecosystems. Though our analysis is static, i.e., it classifies weather pattern variability over a fixed period (1950-2002); it has utility for detecting long-term climate change. For example, we examined the frequency of each weather pattern over time to determine if there were trends. The presence of trends in weather pattern frequency would indicate a possible change in climate over the $50+$ years in our analysis. We found no significant trends, with the exception of one weather pattern (pattern 5) which had a slight, positive trend (see Miller et al. 2006). Continued monitoring of these weather patterns will be useful for the detection of future climate change and ecosystem responses. We conclude that synoptic climatology has important applications in estuarine and coastal systems, both for classification of interannual weather variability and identification of long-term trends in climate.

Acknowledgements We thank the captains and crew of the R/V Cape Henlopen and the pilots and crew of the Chesapeake Bay Remote Sensing Program. We also thank B. Yarnal and R. Wood for the advice on synoptic climatology. This research was funded by the National Science Foundation Land Margin Ecosystem Research Program (DEB-9412133), Sloan Foundation Census of Marine Life Program (2001-3-8), United States Environmental Protection Agency Science to Achieve Results Program (R82867701), National Aeronautics and Space Administration (NASA) component (NAG511302), Maryland Sea Grant (NA05AR417042NOAA), National Oceanic and Atmospheric Administration Coastal Ocean Program (NA17OP2656), and NASA Graduate Student Research Program (NGTS-30485). This is UMCES contribution \#4252.

\section{References}

Beamish, R.J., and D.J. Noakes. 2002. The role of climate in the past, present, and future of Pacific salmon fisheries off the west coast of Canada. In The role of climate in the past, present, and future of Pacific salmon fisheries off the west coast of Canada, ed. N.A. McGinn, 231-244. Bethesda: American Fisheries Society.

Brander, K.M. 2007. Global fish production and climate change. Proceedings of the National Academy of Sciences of the United States of America 104: 19709-19714.
Breitburg, D.L., and R.S. Fulford. 2006. Oyster-sea nettle interdependence and altered control within the Chesapeake Bay ecosystem. Estuaries and Coasts 29: 776-784.

Brunel, T., and J. Boucher. 2007. Long-term trends in fish recruitment in the north-east Atlantic related to climate change. Fisheries Oceanography 16: 336-349.

Cargo, D.G., and D.R. King. 1990. Forecasting the abundance of the sea nettle Chrysaora quinquecirrha, in the Chesapeake Bay. Estuaries 13: 486-491.

Cloern, J.E. 1996. Phytoplankton bloom dynamics in coastal ecosystems: A review with some general lessons from sustained investigation of San Francisco Bay, California. Reviews of Geophysics 34: 127-168.

Cloern, J.E., A.E. Alpine, B.E. Cole, R.L.J. Wong, J.F. Arthur, and M. D. Ball. 1983. River discharge controls phytoplankton dynamics in the northern San-Francisco Bay Estuary. Estuarine Coastal and Shelf Science 16: 415-429.

Cronin, T., D. Willard, A. Karlsen, S. Ishman, S. Verardo, J. McGeehin, R. Kerhin, C. Holmes, S. Colman, and A. Zimmerman. 2000. Climatic variability in the eastern United States over the past millennium from Chesapeake Bay sediments. Geology 28: 36.

Dippner, J.W., J. Hanninen, H. Kuosa, and I. Vuorinen. 2001. The influence of climate variability on zooplankton abundance in the Northern Baltic Archipelago Sea (SW Finland). ICES Journal of Marine Science 58: 569-578.

Feigenbaum, D., and M. Kelly. 1984. Changes in the lower Chesapeake Bay food chain in presence of the sea nettle Chrysaora quinquecirrha (Scyphomedusa). Marine Ecology Progress Series 19: 39-47.

Fromentin, J.-M., and B. Planque. 1996. Calanus and environment in the eastern North Atlantic. II. Influence of the North Atlantic Oscillation on $C$. finmarchicus and C. helgolandicus. Marine Ecology Progress Series 134: 111-118.

Greene, C.H., and A.J. Pershing. 2007. Climate drives sea change. Science 315: 1084-1085.

Harding, L.W. 1994. Long-term trends in the distribution of phytoplankton in Chesapeake Bay: Roles of light, nutrients and streamflow. Marine Ecology Progress Series 104: 267-291.

Heinle, D.R., R.P. Harris, J.F. Ustach, and D.A. Flemer. 1977. Detritus as food for estuarine copepods. Marine Biology 40: 341-353.

Hollowed, A.B., S.R. Hare, and W.S. Wooster. 2001. Pacific Basin climate variability and patterns of Northeast Pacific marine fish production. Progress in Oceanography 49: 257-282.

Jung, S., and E.D. Houde. 2003. Spatial and temporal variabilities of pelagic fish community structure and distribution in Chesapeake Bay, USA. Estuarine, Coastal and Shelf Science 58: 335-351.

Kimmel, D.G., and M.R. Roman. 2004. Long-term trends in mesozooplankton abundance in Chesapeake Bay USA: Influence of freshwater input. Marine Ecology Progress Series 267: 71-83.

Kimmel, D.G., W.D. Miller, and M.R. Roman. 2006a. Regional scale climate forcing of mesozooplankton dynamics in Chesapeake Bay. Estuaries and Coasts 29: 375-387.

Kimmel, D.G., M.R. Roman, and X. Zhang. 2006b. Spatial and temporal variability in factors controlling mesozooplankton dynamics in Chesapeake Bay: Evidence from biomass size spectra. Limnology and Oceanography 51: 131-141.

Landres, P.B., P. Morgan, and F.J. Swanson. 1999. Overview of the use of natural variability concepts in managing ecological systems. Ecological Applications 9: 1179-1188.

Lehman, P.W. 2004. The influence of climate on mechanistic pathways that affect lower food web production in northern San Francisco Bay estuary. Estuaries 27: 311-324.

Livingston, R., X. Niu, F. Lewis III, and G. Woodsum. 1997. Freshwater input to a gulf estuary: Long-term control of trophic organization. Ecological Applications 7: 277-299. 
Macauley, J.M., V.D. Engle, J.K. Summers, J.R. Clark, and D.A. Flemer. 1995. An assessment of water-quality and primary productivity in Perdido Bay, a Northern Gulf-of-Mexico estuary. Environmental Monitoring and Assessment 36: 191-205.

Martino, E.J. 2008. Environmental controls and biological constraints on recruitment of striped bass Morone saxatilis in Chesapeake Bay. Ph.D. Dissertation, University of Maryland College Park.

Miller, W.D., and L.W. Harding. 2007. Climate forcing of the spring bloom in Chesapeake Bay. Marine Ecology Progress Series 331:11-22.

Miller, W.D., D.G. Kimmel, and L.W. Harding. 2006. Predicting spring discharge of the Susquehanna River from a winter synoptic climatology for the eastern United States. Water Resources Research 42:W05414. doi:10.1029/2005WR004270.

Najjar, R.G. 1999. The water balance of the Susquehanna River Basin and its response to climate change. Journal of Hydrology 219: 719.

North, E.W., and E.D. Houde. 2006. Retention mechanisms of white perch (Morone americana) and striped bass (Morone saxatilis) early-life stages in an estuarine turbidity maximum: An integrative fixed-location and mapping approach. Fisheries Oceanography 15: 429-450.

Ottersen, G., B. Planque, A. Belgrano, E. Post, P.C. Reid, and N.C. Stenseth. 2001. Ecological effects of the North Atlantic Oscillation. Oecologia 128: 1-14.

Paerl, H.W., L.M. Valdes, B.L. Peierls, J.E. Adolf, and L.W. Harding. 2006a. Anthropogenic and climatic influences on the eutrophication of large estuarine ecosystems. Limnology and Oceanography 51: 448-462.

Paerl, H.W., L.M. Valdes, A.R. Joyner, B.L. Peierls, M.F. Piehler, S.R. Riggs, R.R. Christian, L.A. Eby, L.B. Crowder, J.S. Ramus, E.J. Clesceri, C.P. Buzzelli, and R.A. Luettich. 2006b. Ecological response to hurricane events in the Pamlico Sound system, North Carolina, and implications for assessment and management in a regime of increased frequency. Estuaries and Coasts 29: 10331045 .

Pearcy, W.G., and A. Schoener. 1987. Changes in the marine biota coincident with the 1982-1983 El Nino in the northeastern subarctic Pacific Ocean. Journal of Geophysical Research 92: 14417-14428.

Purcell, J.E., and M.B. Decker. 2005. Effects of climate on relative predation by scyphomedusae and ctenophores on copepods in
Chesapeake Bay during 1987-2000. Limnology and Oceanography 50: $376-387$.

Purcell, J.E., J.R. White, D.A. Nemazie, and D.A. Wright. 1999. Temperature, salinity and food effects on asexual reproduction and abundance of the scyphozoan Chrysaora quinquecirrha. Marine Ecology Progress Series 180: 187-196.

Secor, D.H., and E.D. Houde. 1995. Temperature effects on the timing of striped bass egg production, larval viability, and recruitment potential in the Patuxent River (Chesapeake Bay). Estuaries 18: $527-544$.

Sherman, K., M. Sissenwine, V. Christensen, A. Duda, G. Hempel, C. Ibe, S. Levin, D. Lluch-Belda, G. Matishov, J. McGlade, M. O'Toole, S. Seitzinger, R. Serra, H.R. Skjoldal, Q. Tang, J. Thulin, V. Vandeweerd, and K. Zwanenburg. 2006. A global movement toward an ecosystem approach to management of marine resources. Marine Ecology Progress Series 300: 274-279.

Sokal, R.R., and F.J. Rohlf. 1995. Biometry. 3rd ed. New York: Freeman.

Steele, J.H. 2004. Regime shifts in the ocean: Reconciling observations and theory. Progress in Oceanography 60: 135-141.

Stenevik, E.K., and S. Sundby. 2007. Impacts of climate change on commercial fish stocks in Norwegian waters. Marine Policy 31: 19-31.

Stenseth, N.C., A. Mysterud, G. Ottersen, J.W. Hurrell, K.-S. Chan, and M. Lima. 2002. Ecological effects of climate fluctuations. Science 297: 1296.

Stenseth, N.C., G. Ottersen, J.W. Hurrell, A. Mysterud, M. Lima, K.-S. Chan, N.G. Yoccoz, and B. Adlandsvik. 2003. Studying climate effects on ecology through the use of climate indices: The North Atlantic Oscillation, El Nino Southern Oscillation and beyond. Proceedings of the Royal Society of London B 270: 2087-2096.

Sugimoto, T., S. Kimura, and K. Tadokoro. 2001. Impact of El Nino events and climate regime shift on living resources in the western North Pacific. Progress in Oceanography 49: 113-127.

Tootle, G.A., T.C. Piechota, and A. Singh. 2005. Couple oceanicatmospheric variability and U.S. streamflow. Water Resources Research 41:W12408. doi:10.1029/2005WR004381.

Wood, R.J. 2000. Synoptic scale climatic forcing of multispecies fish recruitment patterns in Chesapeake Bay. Ph.D. Dissertation. The College of William and Mary, pp. 146.

Yarnal, B. 1993. Synoptic Climatology in Environmental Analysis: A Primer. New York: Wiley. 